\title{
Yabancı dil öğretmenlerinin yansıtıcı öğretime yönelik tutumlarının incelenmesi
}

\author{
Mithat KORUMAZ \\ Rüçhan ÖZKILIÇ
}

Özet

Bu araştırma, İngilizce öğretmenlerinin yansıtıcı öğretime yönelik tutumlarını belirlemek amacıyla yapılmıştır. Nicel araştırma yönteminin kullanıldığı, tarama modelindeki bu araştırmanın örneklemini Bursa Büyükşehir Belediyesi sınırları içerisinde yer alan toplam 25 resmi ilkokul, ortaokul ve lisede görevli 106 İngilizce öğretmeni oluşturmaktadır. Araştırmanın verileri, Akbari, Bahzadpoor ve Dadvand tarafından geliştirilen "Yansıtıcı Öğretim Tutum Ölçeği” ile toplanmıştır. Araştırma kapsamında elde edilen veriler, bireye özgü ve örgütsel değişkenler açısından incelenmiştir. Araştırma kapsamında ulaşılan sonuçlara göre öğretmenlerin yansıtıcı öğretime yönelik tutumlarının genel olarak olumlu düzeyde olduğu sonucuna ulaşılmıştır. Bunun yanında öğretmenlerin cinsiyetlerine göre yansıtıcı öğretime yönelik tutumlarında, kadın öğretmenler lehinde anlamlı bir farklılık olduğu sonucuna ulaşılmıştır. Araştırmada diğer bireye özgü (mezun olunan fakülte türü, en son mezun olunan eğitim seviyesi, mesleki kıdemi) ve örgütsel (kurum türü ve haftalık ders saati) değişkenler açısından öğretmenlerin yansıtıcı öğretime yönelik tutumlarının farklılaşmadığı sonucuna varılmıştır. Ulaşılan bu sonuçlar doğrultusunda uygulayıcılar için, öğretmenlerin mesleki gelişimlerinde önemli bir unsur olarak nitelenen yansıtıcı öğretimle ilgili öğretmenlerle mevcut uygulamaların paylaşılması ve yaygınlaştırılmasına ilişkin önerilerde bulunulmuştur. Bunun yanı sıra araştırmacılar için öğretmenlerin yansıtıcı öğretime yönelik, tutumları, inançları ve uygulamaları bağlamında yapılacak çalışmaların derinleştirilmesine yönelik öneriler sunulmuştur.

Anahtar kelimeler: Yansıtıcı öğretim, mesleki gelişim, tutum, yabancı dil öğretmenleri

\footnotetext{
* Bu çalışma; Mithat Korumaz tarafından Doç. Dr. Rüçhan Özkılıç danışmanlığında tamamlanan "İngilizce öğretmenlerinin yansıtıcı öğretime yönelik tutumları” başlıklı yüksek lisans tez çalışmasından üretilmiştir.

** Arş.Gör., Yıldız Teknik Üniversitesi, Eğitim Fakültesi, Eğitim Bilimleri Bölümü, mkorumaz@yildiz.edu.tr

*** Doç.Dr., Uludağ Üniversitesi, Eğitim Fakültesi, Eğitim Bilimleri Bölümü, ruchan@uludag.edu.tr
} 


\title{
Investigation of EFL teachers' attitudes towards reflective teaching
}

\begin{abstract}
The study aims to investigate the attitudes of EFL teachers' towards reflective teaching. This study is predicated on a descriptive survey of quantitative research designs, sample of which consists of 106 EFL teachers from different 25 state schools in Bursa. For the collection of data, Reflective Teaching Attitude Scale, developed by Akbari, Bahzaadpoor and Dadvand is used. The results adresses both for individual and organizational variables. As a result it is clearly indicated that teacher's attitudes are quite positive. By the way female teachers have more positive attitudes than males significantly. But other individual and organizational variables are not significant ones for the attitudes towards reflective teaching for EFL teachers. In the light of the result of the study it is highly recommended that teachers' knowledge should be raised by the school leaders for their professional development. Another aspect of the study needs to be recommended that studies for deeper understanding should be conducted by the researchers from different disciplines.
\end{abstract}

Keywords: Reflective teaching, professional development, attitudes, EFL teachers

\section{Giriş}

Öğrenme ve öğretimde etkililiği artırmak amacıyla eğitimin farklı alanlarına yönelik birçok çalışma yapılmıştır. Yapılan çalışmalarda yöneltilen temel sorulardan biri, etkili öğrenme ya da öğretim nedir sorusudur. Bu soruya, farklı felsefi, kuramsal ve uygulama-merkezli boyutlardan yaklaşılarak değişik yanıtlar aranmıştır (Ekiz ve Yiğit, 2007). Temelini realizmden alan "daimicilik" eğitim felsefesi, eğitimin evrensel nitelikteki belli gerçeklere göre şekillendirilmesi ve insanların değişmez bu gerçekler ışığında yetiştirilmesi gerektiğini savunur. Belli başlı bir felsefeye dayanmayan ve doğudan bir eğitim hareketi olarak ortaya çıkan "esasicilik" eğitim felsefesine göre bütün insanların sahip olması gereken ve geçmişten gelen temel konu ve değerler korunup öğretilmelidir. Etkili öğrenme ve öğretim ancak bu şekilde sağlanabilir. Öğrenmenin ve öğretimin temelinde "zihin" vardır. Değişmeyi gerçeğin esası olarak gören pragmatik felsefeye dayanan "ilerlemecilik" eğitim felsefesi, eğitimin tecrübenin sürekli olarak yeniden inşa edilmesi ve geçmişteki yaşantılara dayalı olarak, gelecekteki davranışların şekillendirilmesi olduğunu savunur. Son olarak temelini pragmatizm ve varoluşçuluktan alan "yeniden kurmacıllk" eğitim felsefesi ise eğitimin toplumsal dönüşümün en önemli araçlarından biri olduğunu savunmaktadır (Demirel, 2009). Etkin öğretim, sorgulama ve kavramsallaştırma gibi karmaşık, zor ve ustalık gerektiren becerilerin harekete geçirildiği etkin bir süreci ifade eder (Bliss, 1997).

Etkili öğrenme ve öğretimi gerçekleştirmek için etkili öğretmen yetiştirilmesi amacıyla neler yapılması gerektiğine yönelik tartı̧̧a ve öneriler de zaman zaman gündeme gelmiştir (Calderhead, 1988; Ekiz, 2003; Ekiz, ve Yiğit, 2006; Harvard ve Hodkinson, 1994; Pollard, 2002; Senemoğlu, 2003; Wallace, 1991). Tartışma ve önerilerde öğretmen adaylarının öğretmeyi nasıl öğrendikleri, öğretim sürecinde neye değer verdikleri, neyi benimsedikleri, hangi bilgiyi (kurama veya uygulamaya dayalı) etkin olarak kullandıkları, kuramsal bilgiyiöğrenmelerive kullanmalarına yönelik açıklamalar bulunmaktadır. Açıklamalara paralel olarak, öğretmen yetiştirme alanına 
ait çeşitli yaklaşım ve modeller de geliştirilmiştir. Öğretmen eğitimi programları teoriye dayalı öğretmen merkezli yaklaşımdan daha çok uygulamaya dayalı öğrenci merkezli yaklaşıma doğru kaymıştır (Kılıç, 2006).

Günümüze kadar yaygın bir şekilde kabul gören öğretmen yetiştirme modelleri; model merkezli öğretmen yetiştirme modeli, insancıl kurama dayalı öğretmen yetiştirme modeli, yapısalcı kurama dayalı öğretmen yetiştirme modeli ve yansıtma modelidir. Uygulamada ise şimdiye kadar kendini belirgin şekilde gösteren üç genel öğretmen yetiştirme modeli bulunmaktadır. Bunlar; beceri modeli, uygulanmış bilim modeli ve yansıtma modelidir (Wallace, 1991).

Beceri modelinin temelinde "yaparak-yaşayarak öğrenme" yaklaşımı bulunur. Bu model, öğretmenlik bilgi ve becerisinin ancak ve ancak gözlem ve deneyimle kazanılabileceğini savunur (Smith, 1999). Özellikle 1950'li yıllardan itibaren geliştirilmeye ve kullanılmaya çalışılan uygulanmış bilim modeli, uygulamalarını eğitim psikolojisindeki bulgulara dayandırır. Bu model, rasyonel yaklaşım olarak da bilinmektedir (Ekiz ve Yiğit, 2006). Model, eğitim alanında yapılan bilimsel araştırma verilerinden eğitim-öğretim uygulamalarında yararlanılması gerektiğini savunur. Yansıtma modeline göre ise öğretmen adayı, kuramsal olarak öğrendiği bilgi ve öğretmenlik deneyimine yönelik kazandığı bilgi ve becerilerini uygulamada etkin olarak kullanır. Hem kuramsal olarak öğrendiği hem de deneyimlerinden oluşturduğu bilgiden yararlanan aday, herhangi bir okul ya da sınıf ortamında uygulama yapar. Uygulamada karşılaştığı herhangi bir sorunu, edindiği kuramsal bilgileri de göz önüne alarak, sorunu ortadan kaldırmak ya da uygulamayı daha etkili hâle dönüştürmek için etkin, ısrarlı ve sistematik bir biçimde etraflıca düşünür. Düşünme sonucunda yapılandırdığı yeni bilgi ve becerileri tekrar uygulamada kullanır.

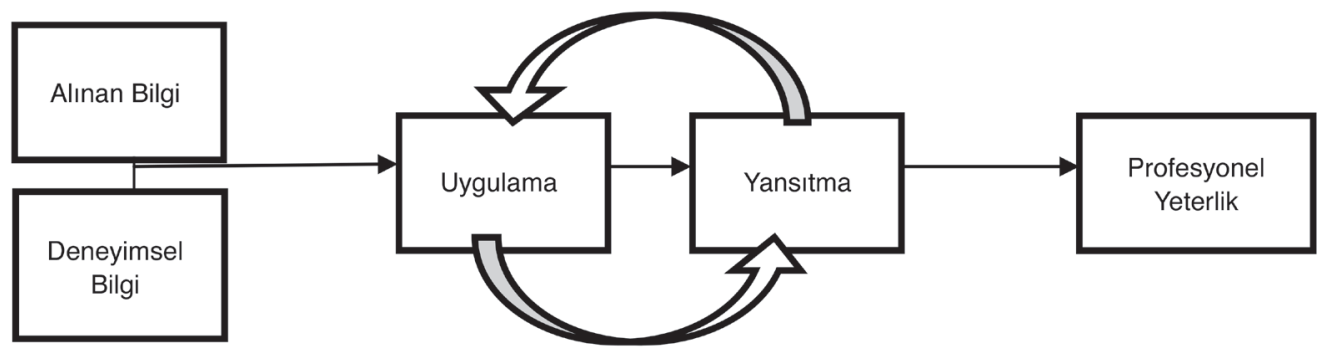

Şekil I. Ekiz, D. (2003). An analysis of the content of the curriculum for the primary phase in Turkey: theoretical underpinnings and practice. Kastamonu Education Journal, 11(1), 31-52.

Aynı şekilde bu döngü devam eder. Yansıtıcı düşünme ve öğretimi gerçekleştirdikten sonra profesyonel (mesleki) yeterliliği kazanır ve öğretmen olur (Ekiz, 2003). Yansıtıcı modelin en belirgin özelliği, hem bilimsel araştırmalara dayalı bilgilerden yararlanılması hem de bu bilgilerin uygulamaya aktarılırken sorgulanarak öğretmen ya da aday öğretmen tarafından karar verme sürecine dâhil edilmesidir (Ekiz ve Yiğit, 2007). 


\section{Yansıtma kavramı ve yansıtıcı öğretim}

Yansıtma kelimesinin eğitimle ilgili sözlük anlamı; "Bir kişinin, düşüncelerini bir konu üzerinde yoğunlaştırması, olayı farkında olarak dikkatli bir biçimde ele almasıdır” (Higgleton, 1995). Tarihsel olarak ele alındığında "yansıtma” kavramını ilk olarak, Platon, Aristo, Konfüçyüs, Lao Tzu, Solomon ve Buda gibi eğitimcilerin fikirlerini temel alan Dewey’in ortaya koyduğu bilinmektedir. Dewey, bu kavramı özel bir problem çözme şekli (yöntemi), birbiri ile ilintili konularla ilgili karar verme süreci, kendinden önceki fikirlerle yeni fikirlerin dikkatlice sıralanması olarak görmüştür. Onun temel fikirleri yol gösterici niteliktedir ve yansıtmanın, inanç ve bilginin altında yatan birbirinden bağımsız düşüncelerin sıralanmasını içeren, aktif, bilinçli, bilişsel ve duyuşsal bir süreç olarak tanımlanabileceğini göstermiştir. Yansıtıcı düşünce genel olarak muhtemel sonuçlara ulaşmadan önce bir belirsizlik ve şüphe durumu yaratan pratik problemlere işaret eder.

"Yansitma hareketi"ne "The Reflective Practitioner (1983)" ve "Educating the Reflective Practitioner (1987)" adlı kitaplarıyla Donald Schön öncülük etmiştir. Schön’un "yansıtıcı uygulama” fikri aslında Dewey’in 1930'ların başında ortaya koyduğu "yansitıcı düşünme” kavramının yeniden ve genişletilerek ortaya konmasıdır (Loughran, 1996; Pollard ve Tann, 1994; Weshah, 2007). Dewey temelini oluşturduğu yansıtıcı düşünme kavramını, herhangi bir bilgiyi ve onun amaçladığı sonuçlara ulaşmayı destekleyen bir bilgi yapısını etkin, sürekli ve dikkatli bir biçimde düşünme olarak tanımlamaktadır. Dewey’in “yansıtıcı düşünme” tanımında; bir durumun içerisinde olunması, problemin hissedilmesi, toplanan bilgiyle problemin netleştirilmesi, önerilen çözümlerin denenmesi ve fikirlerin uygulamalarla sınanması yer almaktadır (Ornstein ve Hunkins, 1993).

Son yirmi yılı aşkın süredir, hizmet-içi ve hizmet öncesi öğretmen eğitiminde yansıtıcı öğretim becerilerinin öğretilmesi yönünde bir eğilim vardır. Yansıtıcı öğretimi, uygulama süreci, bireylerle çalışmak, sınıf ortamlarını oluşturmak, öğretimi planlamak ve yönetmek, içeriğin seçimi ve bireysel yeterlilik gibi sınıf içi durumlarla ilgili detaylı bilgi toplanmasıyla meydana gelir (Ogonor ve Badmus, 2006). Pennington (1992) yansıtıcı öğretimi "deneyimler hakkında derinlemesine düşünülmesi ve bu deneyimlerin yansıması” olarak tanımlamaktadır.

Cruickshank ve Applegate (1981)'e göre yansitma, öğretmenlerin öğretim sürecinde ne meydana geldiğini, niçin meydana geldiğini, daha etkili bir öğretim için neyin yapılabilir fakat yapılmamış olduğunu ve öğretim performanslarının geliştirilmesi için ne gibi değişikliklerin yapılması gerektiği ile ilgili düşünmelerinde yardım edilebilmesi için kullanılan bir araçtır. Ayrıca yansıtıcı öğretim, öğretmenlerin sınıf içi süreçlerde meydana gelen olaylar ve amaçlar ile hedeflere ulaşmak adına alternatif yollar hakkında düşünmesi; öğretimle ilgili nesnel analitik ve derinlemesine düşünme imkânı sunan bir araçtır. Öğretmenler araştırma süreçlerinde sadece öğretmen olarak değil aynı zamanda araştırmacı olarak da yer almak durumundadırlar (Altrichter, Feldman, Posch, ve Somekh, 2008; Carr ve Kemmis, 1986). Richards (1990) yansıtmayı öğretmen gelişiminin anahtar öğesi olarak görmüştür. 


\section{Yansıtma türleri}

Schön (1983), başlangıçta yansıtmanın iki türü olan; "eylem hakkında (öğretim hakkında) yansitma" ve "eylemde (öğretimde) yansitma" üzerinde yoğunlaşırken sonradan üçüncü bir tür olan "eylem için (öğretim için) yansıtma" kavramını ortaya atmıştır. Yansıtmanın bu açıdan türlerine ayrılması yansıtmanın zamanlaması üzerinde durulduğunu göstermesi açısından önemlidir.

\section{Eylem (öğretim) hakkında yansıtma}

Öğretim eyleminin gerçekleşmesinin ardından sonraki eylemlere ışık tutması ya da sonraki eylemlerin planlanması için uygulanmış olan öğretim eyleminin sistematik ve tutarlı bir süreç içerisinde yansitılmasıdır. Bu yansıtma türünde önemli olan nokta yansıtmanın öğretim eyleminin hemen ardından yapılmasıdır (Schön, 1983; akt. Korumaz ve Karakaş, 2014).

\section{Eylemde (öğretimde) yansıtma}

Öğretim eylemine aktif bir biçimde devam ederken yapılan yansıtma ve karar kılma sürecini ifade etmektedir. Schon (1987)'e göre eylemde yansıtma sınıf içinde öğretim gerçekleşirken onunla ilgili düşünülüyor olmasıdır. Bu durumda yansıtma bağlam temellidir (Day, 1999). Öğretmenin içinde bulunduğu bağlamı göz önüne alarak değerlendirmede bulunması oldukça önemlidir. Bu yapıyor olduğumuz işle ilgili düşünmekten çok daha fazlasını ifade etmektedir. Anlık analiz ve muhakeme yeteneğini gerektirir ve bu yüzdendir ki birçok eğitimci ve araştırmacı bu tür öğretimin ve uygulamanın çok daha zor olduğu kanısındadır (akt. Korumaz ve Karakaş, 2014).

\section{Eylem için (öğretim için) yansıtma}

Yansıtıcı uygulamalar yapmak isteyenlere şimdiye kadar edindiklerini anımsamaları ve sonraki bölümlerde neler yapacaklarını daha bilinçli bir şekilde planlamaları için olanak sağlayabilecek bilişsel bir süreci ifade etmektedir. Bu tür yansıtmada ideal olan, eleştirel pedagojiyi ve öğretmenlerin öğretimle ilgili farklı bakış açılarını analiz etmelerine olanak tanıyan pedagojik teorileri de içermesidir (Weshah, 2007; akt. Korumaz ve Karakaş, 2014).

\section{Öğretimde yansıtma alanları}

Yansıtma alanları; teknik, uygulama ve eleştirel olmak üzere üç farklı alanda gerçekleşmektedir. En temel yansıtma alanı teknik yansıtma alanıdır. Kuram ve uygulamaya ilişkin bilginin artması, yansıtma alanlarının genişlemesi ve üst düzey yansıtma alanları olan uygulama ve eleştirel yansıtmaya geçişte ön şart olarak kabul edilmektedir (Korumaz ve Karakaş, 2014). Teknik yansıtma alanında, öğretmen yalnızca bir amaç için eğitsel bilgi ve eğitim programı ilkelerinin teknik uygulamasını düşünür (Demirel, 2010). Ayrıca okul, sınıf ve toplumun kurumsal yapıları problem olarak kabul edilmez (Zeichner ve Liston, 1987). Uygulama yansıtma alanı, varsayımların açığa kavuşturulup detaylı hale getirilmesi ile sınıf içi uygulamalarla ilgili ön hazırlıklarla ilgili yansıtma faaliyetlerini kapsamaktadır. Uygulama alanı, teori ve uygulama arasındaki ilişki gibi pedagojik konularla ilgilidir. Öğretmenler uygulamada yaptıkları seçimleri yansıtır. Seçimlerini 
etkileyen bilişsel, toplumsal ve tarihsel etmenler ve uygulamayı etkileyen örtük programı analiz ederler (Zeichner, 1993). Eleştirel yansıtma alanı öğretim uygulamalarıyla doğrudan veya dolaylı olarak ilgili etik ve ahlaki konuların sorgulanmasıyla ilgilidir. Bu seviyede öğretime ilişkin etik ve politik tasarılara yer verilir. Program tasarımında, eșitlik, serbestlik ve haklılık gibi konular göz önünde bulundurulur. Öğretmen bu aşamada bireysel değerlendirmeden uzak, öğrencilerine fayda sağlayacak bilgi ve sosyal durumları belirler. Öğretmen evrensel bir düşünüş tarzına sahip olmalıdır. Collier (1999) en üst düzey yansıtma alanının "derinlemesine düşünme" evresi olduğu kanısındadır (Taggart, 2005). Sınıf içi uygulamalar, toplumsal konular söz konusu olduğunda genellenebilir olmalıdır. Bu alanda düşünenlerin kendilerini yeniden yapılandırma ve kendini gözden geçirme becerileri gelişir. Farklılıkları sınama ve sorunları çözmek için sistematik girişimlerde bulunma konusunda başarıları yüksektir (Demirel, 2010).

\section{Yansıtıcı öğretim araçları}

Kısaca yansıtıcı öğretim, öğrenme/öğretme ortamında olanlar üzerinde düşünüp eylemlerde bir takım değişikliklere gitmek olarak tanımlandığına göre, hem öğretmenlerin hem de öğrencilerin öğrenme/öğretme ortamları hakkında veri toplamaları gerekmektedir. Söz konusu yansıtıcı öğretim araçları tek tek kullanılabileceği gibi derinlemesine bilgi elde edilebilmesi için bir arada da kullanılabilir. Yansıtıcı öğretimin veri toplama araçları şunlardır: Öğretim günlükleri, ders raporları, araştırma ve anketler, eylem araştırmaları, gözlem, ses ve görüntü kayıtları, meslektaş danışması ve öğretim tartışmalarıdır.

Türkiye’de yansıtma, Temel Eğitime Destek Projesi kapsamında, öğretmenler için genel yeterlik alanlarından biri olarak belirlenmiştir (MEB, 2005). Yansıtma, öğrenme ve öğretme deneyimlerinin olduğu kadar, eylem araştırmalarının ve deneyimsel öğrenmenin önemli bir parçasıdır. Milli Eğitim Bakanlığının 2006 yılında yayınlanan "Öğretmen Eğitimi Bileşeni" projesi kapsamında hazırlanan "Öğretmenlik Mesleği Genel Yeterlilikleri” çalışmasında yansıtıcı öğretimin gerekleri "öz değerlendirme yapma, kişisel gelişimi sağlama ve mesleki gelişimleri izleme ve katkı sağlama” alt başlıklarında açıklanmıştır. Buna göre "öz değerlendirme yapma" başlığı altında şu ifadelere yer verilmiştir: "Öğretmen sınıf içi ve dışı çalışmalarını eleştirel bir yaklaşımla analiz edebilmeli, yeni bilgi ve fikirlere açık olarak kendini sürekli geliştirebilmelidir."

Son ylllarda yapılan akademik çalışmalar da etkili biröğretimin gerçekleşebilmesi için süreklilik gösteren gelişim, sorgulama, değişim ve yansıtmaya ihtiyaç duyulduğunu göstermektedir. $\mathrm{Bu}$ açıdan bakıldığında yansıtıcı öğretimle ilgili son yıllarda yansıtmanın doğası, kullanılan stratejiler, gereklilikler ve etkililiği üzerine gerek yurt içinde (Bağcıŏlu, 1999; Bakioğlu ve Dalgıç, 2014; Erginel, 2006; Filiz, 2008; Genç, 2010; Güney, 2008; Karadağ, 2010; Tok, 2008; Yelken ve Duban, 2010) gerekse yurt dişında (Amobi, 2005; Allen ve Casbergue, 1997; Bataineh, Karasnah, Barakat ve Bataineh, 2007; Dillard, 2007; Eugene, 2003; Nolan ve Hillkirk, 1991; Hillkirk, 1993; Kettle ve Sellars, 1996; Lee, 2005; Marcos, Sanches ve Tillema, 2008; Schweiker-Marra, Holmes, Pula ve Pula, 2003; Pedro, 2005; Thorpe, 2004; Wagner, 2006; Lee, 2007; Wubels ve Korthagen, 1990) pek çok araştırma yapılmıştır.

Akademik nitelikte yürütülmüş tüm bu çalışmalar ve eğitimle ilgili kurumların yaptıkları 
değişiklikler, öğretim işini yürütmesi beklenen birincil unsur olan öğretmenin mesleki gelişiminin önemini vurgulamaktadır. Dolayısıyla öğretmenlerin mesleki gelişimlerinde önemli rol oynadığ1 düşünülen yansıtıcı öğretimle ilgili derinlemesine çalışmaların yapılmasına ihtiyaç duyulduğu söylenebilir. Bu noktadan hareketle bu araştırmanın amacı da öğretmenlerin yansıtıcı öğretime yönelik tutumlarının belirlenmesidir.

$\mathrm{Bu}$ doğrultuda araştırmanın problemi; yabancı dil öğretmenlerinin yansıtıcı öğretime yönelik tutumları hangi düzeydedir şeklinde ifade edilebilir. Aynı zamanda araştırma kapsamında yabacı dil öğretmenlerinin yansıtıcı öğretime yönelik tutumları bireye özgü (cinsiyet, mesleki kıdemi) ve örgütsel (haftalık ders saati) değiş̧kenlere göre farklılaşmakta mıdır alt problemlerine cevap aranmıştır.

\section{Yöntem}

$\mathrm{Bu}$ bölümde araştırmanın modeli, örneklem, veri toplama aracı, veri toplama ve analiz işlemleri hakkında bilgi verilmektedir.

\section{Araştırmanın modeli}

$\mathrm{Bu}$ araştırmada, nicel araştırma yöntemleri kullanılarak yabancı dil öğretmenlerinin yansıtıcı öğretime yönelik tutumları belirlenmeye çalışılmıştır. Var olan durumu ortaya koymaya çalıştığından, bu çalışma betimsel nitelikte tarama modelinde bir araştırmadır.

\section{Araştırmanın örneklemi}

Araştırmanın örneklemi olasılık temelli örneklem yöntemlerinden küme örnekleme yöntemiyle belirlenmiştir. Bursa ili büyükşehir sınırları içerisinde yer alan Osmangazi, Yıldırım, Nilüfer, Mudanya ve Gemlik ilçelerinden beşer okul araştırmanın uygulanması için tesadüfi olarak belirlenmiştir. Belirlenen toplam 25 okulda görev yapan araştırmaya katılma konusunda gönüllü 106 İngilizce öğretmeni araştırmanın örneklemini oluşturmaktadır. Katılımcıların \%35,8'i erkek (38 kişi), \%64,2'si (68 kişi) ise kadındır. Araştırmada yer alan öğretmenler Bakioğlu (1996) tarafından önerilen kariyer evrelerine göre değerlendirildiğinde kariyere giriş evresindeki (1-5 yıl) öğretmenlerin oranı \%18,9 (20 kişi), durulma evresindeki (6-10 yıl) öğretmenlerin oranı \%27,4 (29 kişi), deneycilik evresindeki (11-15 yıl) öğretmenlerin oranı \%16 (17 kişi), uzmanlık evresindeki (16-20 yll) öğretmenlerin oranı \%12,3 (13 kişi) ve sakinlik evresindeki (21 yıl ve üzeri) öğretmenler ise \%25,5 (27 kişi) olduğu belirlenmiştir.

Yansıtıcı becerilerin öğretmenler tarafından kullanılabilmesi için yeterli zamana ihtiyaç duyulmaktadır. Bu nedenle öğretmenlerin iş yükünü oluşturan derslerin yoğunluğu önemli bir değişken olarak ortaya çıkmaktadır (Al-Jabri ve Region, 2009). Bunun yanı sıra OECD’nin 2011 de yayınladığı "Bir Bakışta Eğitim Raporu" göz önünde bulundurularak bu çalışmada da haftalık 15-20 saat arası ders okutan öğretmenler bir grup, 21-30 saat arası ders okutan öğretmenler diğer bir gruba ayrılmıştır. Araştırmada yer alan öğretmenlerden \%28,3'ü (30 kişi) 15-20 saat arası ders okutan öğretmenler, \%71,7’si (76 kişi) 21-30 saat arası ders okutan öğretmenlerden oluşmaktadır. 


\section{Veri toplama aracı}

Araştırma betimsel nitelikte bir çalışmadır. Araştırmada Akbari, Bahzadpoor ve Dadvand (2010) tarafından geliştirilen ölçek kullanılmıştır. Ölçme aracının Türkçe’ye çevrilmesinde İngilizce dil uzmanlarının ve eğitim bilimleri uzmanlarının görüşlerine başvurulmuştur. Veri toplama aracı iki ana bölümden oluşmaktadır. Birinci bölüm araştırmaya katılan öğretmenlerin kişisel bilgilerini içermektedir. Bu bölümde yer alan bilgiler araştırmanın bağımsız değişkenlerini oluşturmaktadır. İkinci bölümde ise beş alt boyuta yönelik toplam 29 madde yer almaktadır. Maddeler beşli likert tipinde hazırlanmıştır. Anketteki tutum puanlarının ortalaması "Hiç (1.001.79)", "Nadiren (1.80-2.59)", “Bazen (2.60-3.39)", "Sik sık (3.40-4.19)” ve "Her zaman (4.205.00)" ş̧eklinde derecelendirilmiştir. Ölçekten asgari 29 ve azami 145 puan alınabilmektedir.

\section{Geçerlik ve güvenirlik analizi}

Faktör analizi, bir konuyla ilgili olarak boyutların ölçülmesidir. Bir konuda bir faktörü oluşturan değişken seti, o konunun aynı boyutunu ölçmektedir. Bir konuda deneklerden elde edilen yanıtlardan değişkenler arasındaki korelasyonun hesaplanması, aralarında ilişki bulunan ve aynı boyutu ölçen değişkenlerin gruplandırılması işlemi sonucunda faktörler belirlenmektedir. $\mathrm{Bu}$ analiz belirli bir konuyu ölçmek amacı ile hazırlanmış olan ölçeğin yapı geçerliliğini göstermektedir (Ural ve Kılıç, 2005). Ölçeğin yapı geçerliğine kanıt sağlamak ve ölçeğin faktör yapısını incelemek için temel bileşenler faktör analizi uygulanmış ve madde seçme ve maddenin uygunluğuna ilişkin karar vermeye dayanak sağlayan kriter faktör yük değeri 0,30 ve üzeri olarak alınmıştır. Ayrıca, öz değeri 1'den büyük olan faktörler üzerinde işlem yapılmıştır.

Öncelikle faktör analizini uygulanacak veri setinin analiz için uygunluğunun değerlendirilmesinde Kaiser-Mayer-Olkin (KMO) uygunluk testi ve Barlett testi kullanılmaktadır. KMO testi, değişkenler arasındaki korelasyonları ve faktör analizinin uygunluğunu ölçen uygunluk testidir. Testin değeri 0-1 arasında değişmektedir. KMO değeri, herhangi bir değişkenin diğer değişkenler tarafından hatasız tahmin edilmesi durumunda 1'e eşit olur (Cengiz ve Kılınç, 2007). Bu araştırmada veri setinin analiz için uygunluğunu belirlemek amacıyla yapılan KMO ve Barlett testi sonuçları; KMO testi \%82 ( ,82) çıkarak veri setinin analiz için uygun olduğunu göstermiştir ayrıca Barlett testi de $(\mathrm{p}<.01)$ anlamlı çıkmıştır. Değişkenler arası korelasyonun mevcut olduğu sonucuna ulaşılabilir.

Varimax rotasyon yöntemi kullanılarak yapılan temel bileşenler faktör analizi işlemi sonucunda özdeğerleri 1'den büyük 5 faktör elde edilmiştir. Bu beş faktör toplam varyansın \%65’ini açıklamaktadır. Ölçme aracının Akbari, Behzadpoor ve Dadvand (2010)'ın çalışmalarına paralel olarak beş alt boyuttan oluştuğu tespit edilmiştir. Ölçeğin ilk boyutu yansıtıcı öğretimin içerdiği öğretim günlükleri, ders raporları, araştırma ve anketler, gözlem grup tartışması gibi araçlar ve yansitıcı uygulamalarla ilgili olan uygulama boyutudur. Uygulama boyutu 1, 2, 3, 4, 5, 6 numaralı maddeleri kapsamaktadır. İkinci boyut mesleki gelişimine yönelik çabaların olduğu, küçük çaplı sınıf içi araştırmalar (eylem araştırmaları), alanıyla ilgili konferans ve seminerlere katılma, alanıyla ilgili gelişmeleri takip etmeyi içeren bilişsel boyuttur. Bilişsel boyut 7, 8, 9, 10, 11, 12 numaralı maddeleri içermektedir. Üçüncü boyut öğretmenin öğrencileri ile ilgili yaptığ 1 
yansıtmaları, öğrencilerin nasıl öğreniyor oldukları ve sınıf içerisindeki tutum ve davranışlarını belirlemeye yönelik maddelerin yer aldığı öğrenci boyutudur. Öğrenci boyutu 13, 14, 15 numaralı maddeleri içermektedir. Dördüncü boyut öğretmenin kişiliği ve mesleğe yönelik inançları, kendi uygulamalarını ve tutumlarını nasıl tanımladığı ile ilgili üst biliş boyutudur. Üst biliş boyutu $16,17,18,19,20,21,22$ numaralı maddeleri içermektedir. Beşinci boyut ise pedagojinin sosyopolitik yönleriyle ve bu sosyo-politik yönlerle ilgili yansıtma eyleminin yapıldığı maddelerini kapsayan, öğretmenlerin uygulamalarında politik önem taşıyan yanlar ve ırk, cinsiyet, sosyal sınıf gibi konuları içeren eleştirel boyuttur. Eleştirel boyut 23, 24, 25, 26, 27, 28,29 numaralı maddeleri içermektedir.

Toplam 29 maddeden oluşan ölçme aracının güvenirlik katsayısı $\alpha=0,915$ olarak hesaplanmıştır. George ve Mallery (2003)'e göre $\alpha>0,7$ ise kabul edilebilir, $\alpha>0,8$ iyi ve $\alpha>0,9$ mükemmel düzeyde demektir. Ayrıca her bir boyutun güvenilirliği için iç tutarlılık değerine bakılmıştır. Her boyut için maddelerin boyuttaki tutarlılığını belirlemek amacıyla madde toplam ve madde kalan ilişki değerlerine bakılmıştır. Her bir maddenin madde toplam ve madde kalan değerleri 0.27 'den büyük olduğu için tüm maddelerin toplam boyutla ilişkili olduğu sonucuna ulaşılabilir. Alt boyutlarda elde edilen Cronbach's Alpha değerleri; uygulama boyutu için Cronbach's Alpha $\alpha=0,701$, bilişsel boyut için Cronbach's Alpha değeri $\alpha=0,834$, öğrenci boyutu için ise Cronbach's Alpha değeri $\alpha=0,636$, üst biliş boyutu için Cronbach's Alpha değeri $\alpha=0,839$ ve eleştirel boyutu için Cronbach's Alpha değeri $\alpha=0,775$ olarak hesaplanmıştır.

\section{Verilerin analizi}

Araştırmada öğretmenlerin yansıtıcı öğretime yönelik tutumlarının cinsiyet değişkenine göre farklılaşma düzeyi Mann Whitney $U$ testi ile incelenmiştir. Öğretmenlerin yansıtıcı öğretime yönelik tutumları haftalık ders saati değiş̧enine göre ise ilişkisiz örneklem $t$ testi ile sınanmıştır. Son olarak öğretmenlerin yansıtıcı öğretime yönelik tutumları varyansların homojenlik göstermesi sebebi ile tek yönlü varyans analizi ile test edilmiştir. Değerlendirmelerde anlamlılık düzeyi .05 olarak benimsenmiştir.

\section{Bulgular}

\section{İngilizce öğretmenlerinin yansıtıcı öğretime yönelik tutumlarıyla ilgili bulgular}

Araştırmaya katılan toplam 106 İngilizce öğretmenin ölçekte yer alan her bir boyutta ve toplamda aldıkları puanların aritmetik ortalama ve standart sapma değerleri verilmiştir. 
Tablo I

Ingilizce Öğretmenlerinin Yansıtıcı Öğretime Yönelik Tutumları

\begin{tabular}{|l|c|c|c|c|}
\hline Ölçme Aracının Boyutları & $\begin{array}{l}\text { En Düşüik } \\
\text { Puan }\end{array}$ & En Yüksek Puan & $\bar{X}$ & SS \\
\hline Uygulama & 6 & 30 & 19,73 & 4,00 \\
\hline Biliş & 6 & 30 & 20,55 & 4,39 \\
\hline Öğrenci & 3 & 15 & 11,66 & 2,02 \\
\hline Üst Biliş & 7 & 35 & 30,65 & 3,69 \\
\hline Eleştirel & 7 & 35 & 27,63 & 4,23 \\
\hline Toplam & 29 & 145 & 110,25 & 14,55 \\
\hline
\end{tabular}

Elde edilen verilere göre "uygulama” boyutunda aritmetik ortalama 19,73; "biliş" boyutunda aritmetik ortalama 20,55; “öğrenci” boyutunda aritmetik ortalama 11,66; "üst biliş” boyutunda aritmetik ortalama 30,65; "eleştirel” boyutta aritmetik ortalama 27,63 ve "Yansıtıcı Öğretim Ölçeği” toplam puanına ait aritmetik ortalama ise 110,25 olarak bulunmuştur. Öğretmenlerin ölçekten elde ettikleri toplam puan, yansıtıcı öğretime yönelik tutumlarının olumlu yönde yüksek olduğunu göstermektedir. Ayrıca öğretmenlerin yansıtıcı öğretime yönelik tutumlarının diğer boyutlara oranla olumlu yönde en yüksek olduğu boyutlar üst biliș ve eleştirel boyuttur. Öğretmenlerin tutumlarının olumlu yönde en düşük olduğu boyut ise öğrenci boyutudur.

Ingilizce öğretmenlerinin cinsiyetlerine göre yansıtıcı öğretime yönelik tutumlarıyla ilgili bulgular

Araştırmaya katılan İngilizce öğretmenlerinin yansıtıcı öğretime yönelik tutumlarında cinsiyetlerine göre anlamlı bir farklılık olup olmadığını belirlemek için veriler Mann Whitney $\mathrm{U}$ testi ile analiz edilmiştir. Birbirinden bağımsız gruplardan elde edilen verilerin analizinde Mann Whitney U testinin tercih edilmesinin sebebi yapılan Levene testi sonucunda varyansların homojen olmamasıdır. Yapılan bu Analiz sonucunda kadın öğretmenler ile erkek öğretmenlerin yansıtıcı öğretime yönelik tutumları arasında anlamlı bir farklılık bulunmuştur [U=987,00, p<0.05]. Erkek öğretmenlerin sıra ortalamaları 45,47 iken kadın öğretmenlerin sıra ortalamaları 57,59'dur.

Tablo 2

Cinsiyete göre yansıtıc öğretime yönelik tutumlar

\begin{tabular}{|l|c|c|c|c|c|}
\hline Cinsiyet & $\mathbf{n}$ & Sıra Ortalaması & Sıra Toplamı & U & p \\
\cline { 1 - 4 } Erkek & 38 & 45,47 & 1728,00 & \multirow{2}{*}{987,00} & \multirow{2}{*}{, $\mathbf{0 4 4}$} \\
\cline { 1 - 4 } Kadın & 68 & 57,59 & 3943,00 & & \\
\hline
\end{tabular}


İngilizce öğretmenlerinin yansıtıcı öğretime yönelik tutumlarında cinsiyete göre alt boyutlarda anlamlı bir farklılığın olup olmadığını belirlemek için Mann Withney $U$ testi her alt boyut için uygulanmıştır.

Tablo 3

Cinsiyete Göre Alt Boyutlarda Yansıtıcı Öğretime Yönelik Tutumlar

\begin{tabular}{|c|c|c|c|c|c|c|}
\hline Alt Boyutları & Cinsiyet & $\mathbf{n}$ & Sira Ortalaması & Sira Toplamı & $\mathbf{U}$ & $p$ \\
\hline \multirow{2}{*}{ Uygulama } & Erkek & 38 & 52,04 & 1977,50 & \multirow{2}{*}{1,236} & \multirow{2}{*}{, 714} \\
\hline & Kadın & 68 & 54,32 & 3693,50 & & \\
\hline \multirow{2}{*}{ Biliş } & Erkek & 38 & 51,80 & 1968,50 & \multirow{2}{*}{1,228} & \multirow{2}{*}{,670 } \\
\hline & Kadın & 68 & 54,45 & 3702,50 & & \\
\hline \multirow{2}{*}{ Öğrenci } & Erkek & 38 & 47,05 & 1788,00 & \multirow{2}{*}{1,047} & \multirow{2}{*}{,102 } \\
\hline & Kadın & 68 & 57,10 & 3883,00 & & \\
\hline \multirow{2}{*}{ Üst Biliş } & Erkek & 38 & 45,64 & 1734,50 & \multirow{2}{*}{845,25} & \multirow{2}{*}{,048 } \\
\hline & Kadın & 68 & 57,89 & 3936,50 & & \\
\hline \multirow{2}{*}{ Eleștirel } & Erkek & 38 & 44,03 & 1673,00 & \multirow{2}{*}{932,00} & \multirow{2}{*}{, 017} \\
\hline & Kadın & 68 & 58,79 & 3998,00 & & \\
\hline
\end{tabular}

Yapılan bu analiz sonucunda erkek ve kadın öğretmenlerin yansıtıcı öğretime yönelik tutumları arasında üst biliş boyutunda $[\mathrm{U}=1,784, \mathrm{p}<0.05]$ ve eleştirel boyutta $[\mathrm{U}=932,00, \mathrm{p}<0.05$ ] anlamlı bir farklılık bulunmuştur. Uygulama, biliş ve öğrenci boyutlarında ise anlamlı bir farklılık bulunmamıştır ( $\mathrm{p}>, 05)$.

İngilizce öğretmenlerinin haftalık ders saatlerine göre yansıtıcı öğretime yönelik tutumlarına ait bulgular

Araştırmaya katılan İngilizce öğretmenlerinin yansıtıcı öğretime yönelik tutumlarında haftalık ders saatlerine göre anlamlı bir farklılık olup olmadığını belirlemek için ilişkisiz örneklem $\mathrm{t}$ - testi yapılmıştır. İngilizce öğretmenlerinin yansıtıcı öğretime yönelik tutumlarında haftalık ders saatlerine göre anlamlı bir farklılık bulunmamıştır $\left[\mathrm{t}_{(104)}=-0.24, \mathrm{p}>0.05\right]$.

Tablo 4

Haftalık Ders Saatleri Göre Yansıtıcı Öğretime Yönelik Tutumlar

\begin{tabular}{|l|c|c|c|c|c|c|}
\hline Yoğunluk & $\mathbf{n}$ & $\bar{X}$ & $\mathbf{S}$ & Sd & t & $\boldsymbol{p}$ \\
\hline Az yoğun & 30 & 110.30 & 12,61 & & & \\
\cline { 1 - 5 } Yoğun & 76 & 110.22 & 14.32 & 104 & .024 & .981 \\
\hline
\end{tabular}


Haftalık ders saati 15-20 saat arası olan öğretmenlerin ölçme aracından aldıkları toplam puanların aritmetik ortalaması 110,30 iken 21-30 arası haftalık ders saati olan öğretmenlerin ölçme aracından aldığı toplam puanların aritmetik ortalaması 110,22'dir.

\section{Ingilizce öğretmenlerinin kariyer evrelerine göre yansıtıcı öğretime yönelik tutumlarına ait bulgular}

Araştırmaya katılan İngilizce öğretmenlerinin yansıtıcı öğretime yönelik tutumlarında kariyer evrelerine göre anlamlı bir farklılık olup olmadığını belirlemek için tek yönlü varyans analizi (One-Way ANOVA) yapılmıştır. İngilizce öğretmenlerinin yansıtıcı öğretime yönelik tutumlarında kariyer evrelerine göre anlamlı bir farklılık bulunmamıştır $\left[\mathrm{f}_{(4-101)}=0.493, \mathrm{p}>0.05\right]$.

Tablo 5

Kariyer Evrelerine Göre Yansıtıa Öğretime Yönelik Tek Yönlü Varyans Analizi Betimsel İstatistikleri

\begin{tabular}{|l|c|c|c|}
\hline Kariyer Evreleri & $\mathbf{n}$ & $\bar{X}$ & ss \\
\hline Kariyere Giriş & 20 & 109.70 & 11.49 \\
\hline Durulma & 29 & 108.10 & 14.35 \\
\hline Deneycilik & 17 & 108.88 & 14.29 \\
\hline Uzmanlık & 13 & 111.154 & 14.62 \\
\hline Sakinlik & 27 & 113.19 & 16.20 \\
\hline
\end{tabular}

Tablo 6

Kariyer Evrelerine Göre Yansıtıı Öğretime Yönelik Tek Yönlü Varyans Analizi Sonuçları

\begin{tabular}{|l|c|c|c|c|c|c|}
\hline $\begin{array}{l}\text { Varyansın } \\
\text { Kaynağı }\end{array}$ & $\begin{array}{c}\text { Kareler } \\
\text { Toplamı }\end{array}$ & sd & $\begin{array}{c}\text { Kareler } \\
\text { Ortalaması }\end{array}$ & f & p & Anlamlı Fark \\
\cline { 1 - 5 } Gruplar arası & 425.663 & 4 & 106.416 & \multirow{2}{*}{0.493} & 0.741 & \\
\cline { 1 - 4 } & 21.815 .959 & 101 & 216.00 & & & \\
\hline Toplam & 22.241 .623 & 105 & & & \\
\hline
\end{tabular}

Kariyere giriş evresindeki öğretmenlerin ölçme aracından aldıkları toplam puanların aritmetik ortalaması 109.70 iken durulma evresindeki öğretmenlerin ölçme aracından aldığ toplam puanların aritmetik ortalaması 108.10 'dur. Deneycilik evresindeki öğretmenlerin ölçme aracından aldıkları toplam puanların aritmetik ortalaması 108.88 ve uzmanlık evresindeki öğretmenlerin ölçme aracından aldığı toplam puanların aritmetik ortalaması 111.154’tür. Son olarak sakinlik evresindeki öğretmenlerin ölçme aracından aldıkları toplam puanların aritmetik ortalaması 113.19'dur. 


\section{Tartışma}

Araştırmanın bu bölümünde, 106 İngilizce öğretmeninin yansıtıcı öğretime yönelik tutumlarıyla ilgili ölçme aracından toplanan verilerin analizinden elde edilen bulguların yorumları yer almaktadır. Bulguların yorumlanmasında araştırmanın alt amaçları esas alınarak bir sıralama yapılmıştır.

Tutum puanlarının ortalaması göz önüne alındığında İngilizce öğretmenlerinin yansıtıcı öğretime yönelik tutumlarının olumlu olduğu söylenebilir. Bu sonuca paralel olarak Goodman (1984), Loughran (1995), Carter (1998), Butke (2003), McKeny (2006), Filiz (2008) ve Karadağlı (2010) yaptıkları çalışmalarda öğretmenlerin veya öğretmen adaylarının yansıtıcı öğretime yönelik tutum ve becerilerinin yüksek düzeyde olduğu sonucuna ulaşmışlardır. Öğretmenlerin yansıtıcı öğretime yönelik tutumların olumlu olması öğretmenlerin eylem öncesinde, sırasında ya da sonrasında eylemleri hakkında derinlemesine düşünme ve muhakeme yapma eğiliminde oldukları şeklinde yorumlanabilir. Mewborn (1999), Erginel (2006), Meral (2006), Dolapçığlu (2007), Kaf, Hasırcı ve Sadık (2009), Gipe ve Richards (2010) tarafından yapılan çalışmalarda öğretmenlerin, yansıtıcı düşünme düzeylerini yüksek algıladıkları ve mesleki gelişimlerini önemsedikleri sonucuna ulaşılmıştır. Öğretmenlerin yansıtıcı öğretime yönelik tutumlarının olumlu yönde şekillenmiş olması aynı zamanda öğretmenlerin yansıtıcı düşünme eğiliminde olduklarının ve mesleki gelişime önem verdiklerinin bir göstergesi sayılabilir. Abrams ve Middlleton (2004) ve Weshah (2007) yaptıkları çalışmalarda öğretmenlerin yansıtıcı eylemleri sayesinde, performanslarının kalitesini gözlemleyebildikleri ve mesleki gelişimleri için hangi pedagojik yeteneğe ihtiyaç duyduklarını belirleyebildiklerini ortaya koymuşlardır.

Kadın öğretmenlerin yansıtıcı öğretime yönelik tutumlarının istatistiksel olarak erkek öğretmenlere göre öğretmenin kişiliği ve mesleğe yönelik inançları, kendi uygulamalarını ve tutumlarını nasıl tanımladığı ile ilgili üst biliş ve pedagojinin sosyo-politik yönleriyle, öğretmenlerin uygulamalarında politik önem taşıyan yanlar ve ırk, cinsiyet, sosyal sınıf gibi konuları içeren eleştirel boyutta anlamlı bir şekilde farklı olduğu sonucuna ulaşılmıştır. Yapılan benzer çalışmalarda kadın öğretmenlerin erkek meslektaşlarına göre daha yansıtıcı düşündükleri (Aslan, 2009; Çakır, Kan ve Sünbül, 2006; Özcan, 2002; Deniz, Avşaroğlu ve Fidan, 2006), açık fikirli oldukları (Kaf Hasırcı ve Sadık, 2009; Kılınç, 2010), mesleklerini daha olumlu algıladıkları (Kılınç, 2010) ve iş doyumlarının daha yüksek olduğu (İnce, 2006) görülmektedir (akt. Korumaz ve Karakaş, 2014). Kadınların öğretmenlik mesleğini tercih ederken erkek öğretmenlerden daha bilinçli davrandıklarını (Çelenk, 1988; Övet, 2006) ortaya koyan bulgular benzer sonuçları sunmaktadır. Karadağlı (2010), kadın öğretmenlerin sorgulayıcı ve etkili öğretim, öğretim sorumluluğu ve bilimsellik, araştırmacılık, öngörülü ve içten olma boyutlarında daha yüksek yansıtıcı düşünme eğiliminde olduğunu ve mesleklerini daha olumlu algıladıkları sonucuna ulaşmıştır (akt. Korumaz ve Karakaş, 2014). Kadın öğretmenlerin yansıtıcı öğretime yönelik tutumlarının erkek öğretmenlere göre daha olumlu olduğu sonucuna ulaşılabilir.

Araştırmanın bulguları incelendiğinde İngilizce öğretmenlerinin yansıtıcı öğretime yönelik tutumlarının öğretmenlerin kariyer evrelerine göre anlamlı bir şekilde değişmediği sonucuna 
ulaşılmaktadır. Ancak araştırmanın sonuçlarının aksine, Rodgers (2002), okul yaşantılarında kazanılan deneyimle birlikte öğretmenlerin öğretimi etkileyen durum ve faktörlerin bilincine varma, çözümü üzerinde düşünme ve eyleme geçme için ihtiyaç duyacağı zamanın azaldığ sonucuna ulaşmıştır. Taggart (2005) deneyimle birlikte öğretmenlerin teori ve pratiği bir araya getirmeye yönelik becerilerinin arttığını ortaya koymuşlardır. Dolapçıŏlu (2007) ve Kılınç (2010) yaptığı çalışmalarda da öğretmenlerin mesleki kıdemine paralel olarak yansıtıcı düşünme düzeylerinin de arttığını belirlemişlerdir. Karadağlı (2010) ise mesleki kıdem yılına paralel olarak yansıtma kavramına ilişkin becerilerin artışını deneyimle birlikte artan düşünme becerisinin yanı sıra özgüven, sorumluluk ve mesleği sahiplenme duygularının gelişmesi ile açıklamıştır. Weshah (2007) yaptığı çalışmasında "planlama" ve "uygulama" boyutlarında öğretmenlerin deneyimlerine paralel olarak uygulamaya yönelik becerilerinin arttığını belirlemiş̧ir. Son olarak Minnot (2006) da yürüttüğü çalışmanın sonucunda sınıf içi uygulamalarda deneyimli öğretmenlerin yansıtıcı uygulamalara öncelik verdiklerini ortaya koymuştur. $\mathrm{Bu}$ araştırmada kariyer evrelerinde alınan puanların aritmetik ortalamaları göz önüne alındığında öğretmenlerin yansıtıcı öğretime yönelik tutumlarının istatistiksel olarak anlamlı düzeyde bir farklılık arz etmese de olumlu yönde artı̧̧ gösterdiği sonucu çıkarılabilir.

Araştırmanın bulgularına göre öğretmenlerin haftalık ders saatlerine bakıldığında yansıtıcı öğretime yönelik tutumlarında anlamlı bir farklılık olmadığı sonucuna ulaşılmıştır. Yapılan çalı̧malarda yansıtıcı öğretim stratejileri arasında yer alan; öğretim günlükleri, ders raporları, araştırma ve anketler, eylem araştırmaları, gözlem, ses ve görüntü kayıtları, meslektaş danışması ve öğretim tartışmalarının etkili bir biçimde yürütülmesi büyük ölçüde zaman gerektiren etkinlikler olarak sıralanmaktadır (Andrejewski, 2008; Butke, 2003; Scanlan ve Chernobas, 1997). Haftalık ders etkinliklerinin yansıtıcı öğretim uygulamalarına uygun olması için öğretmenlerin haftalık ders yüklerinin yanı sıra geleneksel ders düzenini yeniden tasarlaması gerekmektedir. Öğretmenlerin eğitim programlarını tamamlamak, etkili ders planları geliştirmek, öğrencileri değerlendirmek, öğrencilerle konuşmak ve onları değerlendirmek, öğrencilerle konuşmak ve onları dinlemek, ailelerle görüşmek, meslektaşları ile iletişim halinde bulunmak, mesleki gelişimleri için yayınları takip etmek vb. için zamana ihtiyaç vardır (Özkılıç ve Korkmaz, 2004).

Araştırmanın bulgu ve sonuçlarına bağlı olarak aşağıdaki önerilerde bulunulabilir:

- Araştırma İngilizce öğretmenlerin yansıtıcı öğretime yönelik tutumlarının yüksek olduğu sonucunu ortaya koymuştur fakat bundan sonraki çalışmalarda İngilizce öğretmenlerinin yansıtıcı öğretim becerilerini ne ölçüde uygulama alanına aktarabildikleri belirlenmeli ve söz konusu becerilerin kullanımının arttırılması için çalışmalar yapılmalıdır.

- Kadın öğretmenlerin yansıtıcı öğretime yönelik tutumlarını erkek öğretmenlere göre anlamlı düzeyde farklı kılan özellikleri daha derinlemesine anlaşılmasına imkân tanıyacak açıklayıcı nitel çalışmalar yapılmalıdır.

- Erkek öğretmenlerin yansıtıcı öğretime yönelik tutumlarının kadın öğretmenlere oranla anlamlı düzeyde düşük düzeyde olmasına neden olan sebepler açılayıcı, derinlemesine bilgi sunan nitel çalışmalar ile belirlenmeli ve bu sebepleri ortadan kaldıracak önlemler alınmalıdır. 


\section{Kaynaklar}

Abrams, E. \& Middleton, M. (2004). Pre-service middle school teachers reflecting on instructional practice through technology. National Educational Computing Konferansında sunulmuş bildiri, New Orleans. ABD.

Akbari,R., Bahzadpoor, F. \& Dadvand B. (2010). Development of English language teaching reflection inventory. System, 38(2), 211-227.

Altrichter, H. Feldman, A., Posch, P., \& Somekh, B. (2008). Teachers investigate their work: An introduction to action research across the professions (2nd ed.). Londra: Routledge.

Allen, R.M. \& Casburgue, R.M. (1997). Evolution of novice through expert teachers recall: implication on practice. Teaching and Teacher Education, 13(7), 741-755.

Amobi, F.A. (2005). Turning the focus on ourselves: teacher education professors' reflectivity on their own teaching, Reflective Practice, 6(2), 311-318.

Andrejewski, C.E. (2008). A holistic investigation of teacher identity, knowledge and practice. (Yayınlanmamış doktora tezi). Ohio State Üniversitesi, Ohio.

Aslan, G. (2009). Sınıf öğretmenlerinin yansıtıcı düşünme eğilimleri ile sürekli kaygı düzeyleri arasındaki ilişki, (Yayınlanmamı̧ yüksek lisans tezi), Yeditepe Üniversitesi, İstanbul.

Bağcıoğlu, G. (1999). Öğretmen adaylarında yansıtıcı düşünmeyi geliştirici etkinlikler. VIII. Ulusal Eğitim Bilimleri Kongresi Bildileriler Kitabı, Karadeniz Teknik Üniversitesi Eğitim Fakültesi, Trabzon.

Bakioğlu, A. (1996). Öğretmenlerin kariyer evreleri. II. Ulusal Eğitim Bilimleri Sempozyumu Bildiriler Kitabı, M.Ü. Atatürk Eğitim Fakültesi Yayınları, İstanbul.

Bakioğlu, A. \& Dalgıç, G. (2014). Eğitimcilerde yansıtıcı düşünme. İstanbul: Bahçeşehir Üniversitesi Yayınları.

Bataineh, R. F., El Karasneh, M.S., Barakat, A. A. \& Bataineh, R. F. (2007). Jordanian pre-service teachers' perceptions of the portfolio as a reflective learning tool, Asia-Pacific Journal of Teacher Education, 35(4), 435-454.

Bliss, J. (1997). Effective teaching and learning: scaffolding revisited. Oxford Review of Education, 22(1), 37-61.

Butke, M.A. (2003). Reflection on practice a study of five choral educators' reflective journeys (Yayınlanmamış doktora tezi), Ohio State Üniversitesi, Ohio.

Calderhead, J. (1988). The development of knowledge structures in learning to teach. In J. Calderhead (Ed.), Teachers' professional learning (ss. 51-64). London \& New York: The Falmer Press.

Carr, W. \& Kemmis, S. (1986). Becoming critical: education, knowledge and actionresearch. Geelong: Deaking University Press.

Carter, C. W. (1998). The use of journals to promote reflection. Action in Teacher Education, 19(4), 39-42.

Cengiz, D. \& Kılınç, B. (2007). Faktör analizi ile 2006 dünya kupasına katılan takımların sıralamasının belirlenmesi. Marmara Üniversitesi İİBF Dergisi, 23(2), 351-370.

Collier, S.T. (1999). Characteristics of reflective thought during the student teaching experience. Journal of Teacher Education, 50(3), 173-181.

Cruickshank, D. \& Applegate, J. (1981). Reflective teaching as a strategy for tender growth. Educational Leadership, 1(1), 553-554.

Çakır, Ö., Kan, A. \& Sünbül, Ö. (2006). Öğretmenlik meslek bilgisi ve tezsiz yüksek lisans programlarının tutum ve özyeterlik açısından değerlendirilmesi, Mersin Üniversitesi Eğitim Fakültesi Dergisi, 2(1), 36-47.

Day, C. (1999). Developing teachers: the challenges of life-long learning. London: Falmer Press.

Demirel, Ö. (2009). Eğitimde program geliştirme. Ankara: Pegem Akademi.

Demirel, Ö. (2010). Eğitimde yeni yönelimler. Ankara: Pegem Akademi. 
Deniz, M., Avşaroğlu, S. \& Fidan, Ö. (2006). İngilizce öğretmenlerinin öğrencileri motive etme düzeylerinin incelenmesi. İnönü Üniversitesi Eğitim Fakültesi Dergisi, 11(7), 61-73.

Dillard, J. (2007). Teachers as reflective practitioners: examining teacher stories of curricular change in a 4 th grade classroom. Journal of Reading Horizons, 47(3), 203-228.

Dolapçığlu, S. D. (2007). Sınıf öğretmenlerinin yansıtıcı düşünme düzeylerinin değerlendirilmesi (Yayınlanmamış yüksek lisans tezi), Mustafa Kemal Üniversitesi, Sosyal Bilimler Enstitüsü, Hatay.

Ekiz, D. (2003). An analysis of the content of the curriculum for the primary phase in Turkey: theoretical underpinnings and practice, Kastamonu Education Journal, 11(1), 31-52.

Ekiz, D. \& Yiğit, N. (2007). Öğretmen adaylarının öğretmen eğitimindeki modeller hakkındaki görüşlerinin program ve cinsiyet değişkenleri açısından incelenmesi. Türk Eğitim Bilimleri Dergisi, 5(3), 571586.

Ekiz, D. \& Yiğit, N. (2006). Öğretmen adaylarının öğretmen eğitimindeki modeller hakkında görüşlerinin farklı programlar açısından incelenmesi. İlköğretim Online, 5(2), 110-122.

Erginel, Ş. S. (2006). Developing reflective teachers: a study on perception and improvement of reflection in preservice teacher education (Yayınlanmamış doktora tezi), Orta Doğu Teknik Üniversitesi, Ankara.

Eugene, K. (2003). Promoting pre-service teacher education students' reflective practice in mathematics. Asia-Pacific Journal of Teacher Education, 31(1), 21-32.

Filiz, Y. (2008). İngilizce öğretmenlerinin yansıtıcı öğretime yaklaşımları (Yayınlanmamış yüksek lisans tezi), Uludağ Üniversitesi, Bursa.

Genç, Z. S. (2010). Teacher autonomy through reflective journals among teachers of eglish as a foreign language in Turkey. Teacher Development, 14(3), 397-409.

George, D. \& Mallery, P. (2003). SPSS for windows step by step: A sample guide \& reference. Boston: Allyn \& Bacon,

Gipe, J.P. \& Richards, J.C. (2010). Reflective thinking and growth in novices' teaching abilities. The Journal of Educational Research, 86(1), 51-57.

Goodman, J. (1984). Reflection and teacher education: A case study and theoretical analysis. Interchange, 15(3), 9-26.

Güney, K. (2008). Mikro-yansıtıcı öğretim yönteminin öğretmen adaylarının sunu performansı ve yansitıcı düşünmesine etkisi (Yayınlanmamış doktora tezi), Fırat Üniversitesi, Sosyal Bilimler Enstitüsü, Elazı̆.

Harvard, G. R. \& Hodkinson, P. (1994). Action and reflection in teacher education. Greenwood.

Higgleton, E. (1995). Chambers english essential english dictionary. Londra: University of Cambridge Press.

İnce, V. M. (2006). İlköğretim 3, 4, 5, 6, 7 ve 8. sınıf öğrencilerinin yazıl anlatım becerilerinin ölçülmesi ve değerlendirilmesi (Yayınlanmamış yüksek lisans tezi), Muğla Üniversitesi, Sosyal Bilimler Enstitüsü, Muğla.

Kaf, Hasırcı, Ö. \& Sadık, F. (2009). Sını öğretmenlerinin yansıtıcı düşünme eğilimlerinin belirlenmesi. 18. Ulusal Eğitim Bilimleri Kurultayı Sözlü Bildiri, Ege Üniversitesi, Eğitim Fakültesi, 1-3 Ekim 2009, İzmir.

Karadağ, M. (2010). Sosyal bilgiler öğretmenlerinin yansitıcı düşünme düzeylerinin belirlenmesi (Yayınlanmamış yüksek lisans tezi), Çukurova Üniversitesi, Adana.

Kettle, B. \& Sellars, N. (1996). The development of student teachers practical theory of teaching. Teaching and Teacher Education, 12(1), 1-24.

Kılıç, A. (2006). Öğretmen adaylarının öğretmenlik becerilerini uygulama ve gözleme düzeyleri. Düzce Üniversitesi Sosyal Bilimler Dergisi, 16, 155-168.

Korumaz, M. \& Karakaş, A. (2014). İngilizce okutmanlarının yansıtıcı öğretime yönelik tutumlarının incelenmesi. Pegem Ĕ̆itim ve Öğretim Dergisi, 4(1), 27-46. 
Lee, H.J. (2005). Understanding and assessing preservice teachers' reflective thinking. Teaching and Teacher Education: An International Journal of Research and Studies, 21(6), 699-715.

Loughran, J. (1995). Practising what i preach: modelling reflective practice to student teachers. Research in Science Education, 25(4), 431-451.

Marcos, J. J. M., Sanchez, E., \& Tilemma, H. (2008). Teachers reflecting on their work: articulating what is said about what is done. Teachers And Teaching: Theory and Practice, 14(2), 95-114.

McKeny, T. S. (2006). A case-study analysis of the critical features within field experience that effected the reflective development of pre-service secondary math teachers. (Yayınlanmamış yüksek lisans tezi), Ohio State Üniversitesi, Ohio.

MEB. (2005). Milli Eğitim Bakanlı̆̆ı Temel Eğitime Destek Programı Öğretmen Eğitimi Bileşeni Öğretmenlik Mesleği Genel Yeterlilikleri Taslağı. Öğretmen Yetiştirme ve Eğitimi Genel Müdürlüğü, Ankara.

Meral, E. (2006). İlköğretim İngilizce programını uygulayan öğretmenlerin eleştirel ve yansıtıcı düşünmeleri (Yayınlanmamış yüksek lisans tezi), Fırat Üniversitesi, Sosyal Bilimler Enstitüsü, Elazığ.

Mewborn, D.S. (1999). Reflective thinking among pre-service math teachers. Journal for Research in Mathematics Education, 30(3), 316-341.

Nolan, J. \& Hillkerk, K. (1991). The effects of a reflective coaching project for veteran teachers. Journal of Curriculum and Supervision, 7(1), 62-76.

Ogonor, B.O. \& Badmus, M. M. (2006). Reflective teaching practice among students teachers: the case in a tertiary institution in Nigeria, Australian Journal of Teacher Education, 31(2), 1-11.

Ornstein, A. \& Hunkins, F. (1993). Curriculum foundations, principles and issues. Allen and Bacon, ABD.

Özcan, T. (2002). İlköğretim sosyal bilgiler dersinin genel amaçlarının öğretmen görüşleri doğrultusunda değerlendirilmesi Kilis ilinde bir araştırma (Yayınlanmamış yüksek lisans tezi), Çukurova Üniversitesi, Sosyal Bilimler Enstitüsü, Adana.

Pedro, J. Y. (2005). Reflection in teacher education: exploring pre service teacher's meanings of reflective practice. Journal Reflective Practice, 6(1), 49-66.

Pennington, M. (1992). Reflecting on teaching and learning: a development focus for the second language classroom, In Perspectives on second language classroom teacher education. eds. J. Flowerdew, M. Brock, and S. Hsia. Kowloon: City Polythenic of Hong Kong.

Pollard, A. (ed.) (2002). Readings for reflective teaching. London: Continuum.

Pollard, A. \& Tann, S. (1994). Reflective teaching in the primary school a handbook for the classroom, 2nd ed. The Open University Press.

Richards, J.C. (1990). Beyond training: approaches to teacher education in language teaching, Journal of Language Teacher, 14(2), 3-8.

Rodgers, C. (2002). Defining reflection: another look at John Dewey and reflective thinking. Teachers College Record, 104(4), 842-866.

Schön, D. (1983). The reflective practitioner. Basic Books. Amerika Birleşik Devletleri.

Schön, D. (1987). Educating the reflection practitioner: Towards a new design for teaching and learning in the profession. San Francisco, CA: Josey-Bass Publishers.

Schweiker-Marra, K. Holmes, J.H. \& Pula, J.J. (2003). Training promotes reflective thinking in pre-service teachers, Delta Kappa Gamma Bulletin.

Senemoğlu, N. (2003). Türkiye'de sınıf öğretmeni yetiştirme uygulamaları, sorunlar, öneriler. SDÜ Burdur Ĕ̆itim Fakültesi Dergisi, 5(4), 154-193.

Smith, E. (1999). Ten years of competency-based training: the experience of accredited training providers in Australia. International Journal of Training and Development, 3(2), 106-117.

Thorpe, K. (2004). Reflective learning journals: from concept to practice. Journal of Reflective Practice, 5(3), 327-343. 
Tok, Ş. (2008). Yansıtıcı düşünceyi geliştirici etkinliklerin öğretmen adaylarının öğretmenlik mesleğine yönelik tutumlarına, performanslarına ve yansıtmalarına etkisi. Eğitim ve Bilim Dergisi, 33(149), 104-117.

Taggart, G. (2005). Promoting reflective thinking in teachers: 50 action strategies, Thousand Oaks, CA: Corwin Press.

Ural, A. \& Kılıç, İ. (2005). Bilimsel araştırma süreci ve SPSS ile veri analizi. Ankara: Detay Yayıncılık. Wallace, M. (1991). Training foreign language teachers. Cambridge: Cambridge University Press.

Weshah, A.H. (2007). Training pre-service teacher education on reflective practice in jordanian universities. European Journal of Scientific Research, 2(18), 306-321.

Wubbels, T. \& Korthagen, F.A.J. (1990). The effects of a pre-service teacher education program for the preparation of reflective teachers. Journal of Education for Teaching, 16(1), 29-43.

Yelken, Y. T. \& Duban, N. (2010). Öğretmen adaylarının yansıtıcı düşünme eğilimleri ve yansıtıcı öğretmen özellikleriyle ilgili görüşleri. Ç.Ü. Sosyal Bilimler Enstitüsü Dergisi, 19(2), 343-360.

Zeichner, K. (1993). Connecting genuine teacher development to struggle for social justice. Journal of Education for Teacher, 19(1), 5-16.

Zeichner, K. M., \& Liston, D. P. (1987). Teaching student teachers to reflect. Harvard Educational Review, 56(1), 23-48. 